\title{
Obituary: Melvin L. Moss (1923-2006)
}

Melvin L. Moss passed away June 25, 2006, at the age of 83. Mel was an anatomist (and former dean) at the dental school at Columbia University, New York (Fig. 1). Indeed, he was very much a home-town success: Born in New York (January 23, 1923), he received his A.B. from New York University (1942), and then his D.D.S. (1946) and his Ph.D. (Anatomy, 1954) from Columbia University. Mel taught at Columbia for the whole of his professional career (Fig. 2), even after receiving his emeritus status in 1993, giving his last formal anatomy lecture in 1993 (Fig. 3).

Labeling Mel as an anatomist is strictly true, but his interests - and his intellectual influence-are more farranging. His over-200 publications spanning some 60 years (including many invited book chapters) is itself a testament to his scientific contributions, but those who were fortunate enough to hear him speak at meetings recognize that his sphere of influence was much broader than can be extracted from his writings alone.

Moss' spectrum of researchinterests ranged from dental histology, tooth formation, odontometrics, bone biology, growth and development, mathematical modeling, branchial arch syndromes, the etiology of malocclusion, anatomical consequences of orthocephalization, and a host of other topics. Mel's command of German provided a valuable prelude into the scientific European literature, so his papers are well-peppered with insights and citations that are less accessible to the rest of us who wrestle with a single language. However, it is Mel's development and vociferous promotion of the functional matrix theory that is his foremost contribution (e.g., Moss-Salentijn, 1997). This involved a true paradigm shift (Kuhn, 1962). Previously (and persistently in some circles), the size and shape of bones were perceived to be the consequence of their genetic endowment. Instead, Moss argued-along with insightful animal experimentation-that bone is "dumb" (an often-repeated metaphor of his), meaning that bone merely responds to the environment (the soft tissues, mechanical demands, etc.) that it finds itself in.

I'm fond of dwelling on this "Moss-ism" in my own lectures, partly because of its interesting structure but also because it is so pithy:

The size, shape, position and maintenance in being of all skeletal units are compensatory, secondary and mechanically obligatory responses to the primary morphogenetic demands of their specifically related functional matrices.

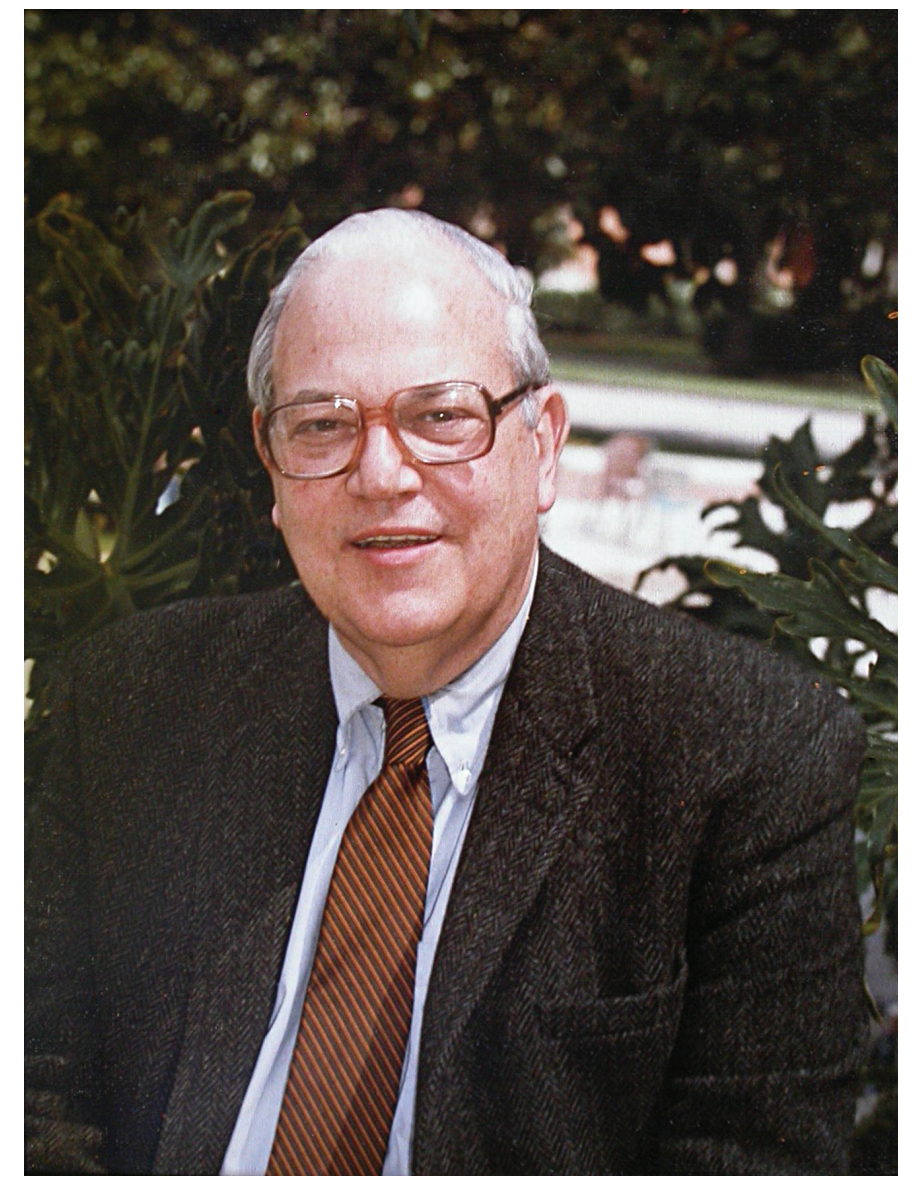

Fig. 1. Mel Moss, mid-1980s.

This meshes with the bone biologists' refrain that "function is dominant over form."

Moss' functional matrix theory rankled more than a few colleagues, commonly generating heated, dynamic discussions at meetings. With his imposing stature, powerful voice, and considerable erudition, arguments with Moss often became lively theater for the audience. Since Moss was such an excellent speaker, he frequently was called on as the scientific expert to open sessions at clinical meetings of dentists (and, especially, orthodontists, who were broadly influenced by the functional matrix theory), so expectations of verbal fireworks between Mel and the antagonist-of-the-day often were fulfilled. Most researchers of his era have "Mel stories." Indeed, he clearly had a Socratic streak in him that enjoyed teaching by raising his opponent's blood pressure.

Development and elaboration of the functional matrix theory held much of Moss' attention during the latter part of the century, so younger scholars can be excused if they 


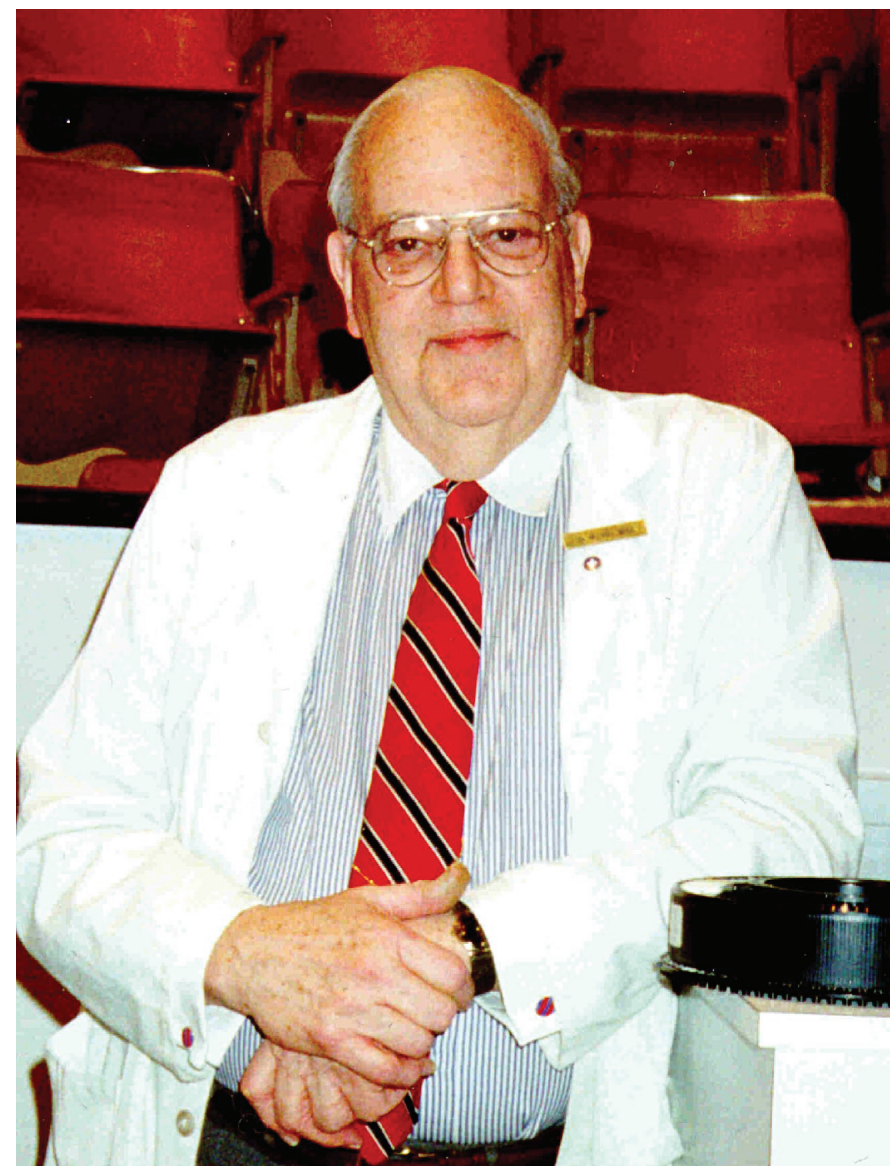

Fig. 1. Mel Moss, 1993, following his final anatomy lecture, and preceding his emeritate.

perceive Moss as a craniofacial biologist. He published widely (with 16 papers in the American Journal of Physical Anthropology), and he did considerable early work on the histology of dental tissues. His work on the phylogeny of mineralized tissues (1964) and the evolution of mammalian dental enamel (1969) are representative of the breadth and scope of his considerable knowledge. Moss participated in several of the International Symposia on Dental Morphology (Moss, 1978, 1982), but he may be best known in dental anthropology circles for his study of tooth sizes of Liberian Negroes (1966, 1967), which is an area of the world that still merits anthropological investigation (Edgar, 2002). Of note, some of Moss' final studies were of teeth (Moss-Salentijn et al., 1997; Moss et al., 2005).

At the risk of being an absurd reductionist, Moss' professional career spanning a half-century offers a special opportunity to reflect on the productivity of an enthusiastic scientist, especially one working before the now-popular multi-author laboratories, where authorship comes more easily, but sole authorship only occurs rarely. Moss' publication record involved several close collaborators over the years, but the work generally reflects the vision of one person. My collation of his references from 1948 through 2005-which is almost guaranteed to be incomplete-comes up with 247 citations $($ mean $=4.3 /$ year; $s d=3.2)$. Moss' productivity picked up in 1954 coincident with award of his Ph.D. (Fig. 4 ), and it seldom dropped below 4 peer-reviewed papers per year for the next 35 years. This sustained output likewise is shown in Fig. 5, where the cumulative curve has a characteristic sigmoid shape due to a hesitant start at the beginning and a decelerating denouement at the end, but I doubt if there are many of Moss' era who match the long, linear, high rate of publication in between. It devalues a scientist's career to merely count the lines on a $\mathrm{CV}$, but these numbers provide an interesting benchmark of one person's research productivity. Unfortunately, they also cloud the powerful and lasting influence Mel had on his students and colleagues.

Edward F. Harris Editor

\section{ACKNOWLEDGEMENT}

Melvin Moss' wife and colleague, Dr. Letty MossSalentijn, kindly provided a CV as well as the three photographs of Mel for this article.

\section{REFERENCES CITED}

Edgar HJH. 2002. Biological distance and the African American dentition. Ph.D. dissertation, Ohio State University.

Kuhn TS. 1962. The structure of scientific revolutions. Chicago: University of Chicago Press.

Moss-Salentijn L. 1997. Discovery! Melvin L. Moss and the functional matrix. J Dent Res 76:1814-1817.

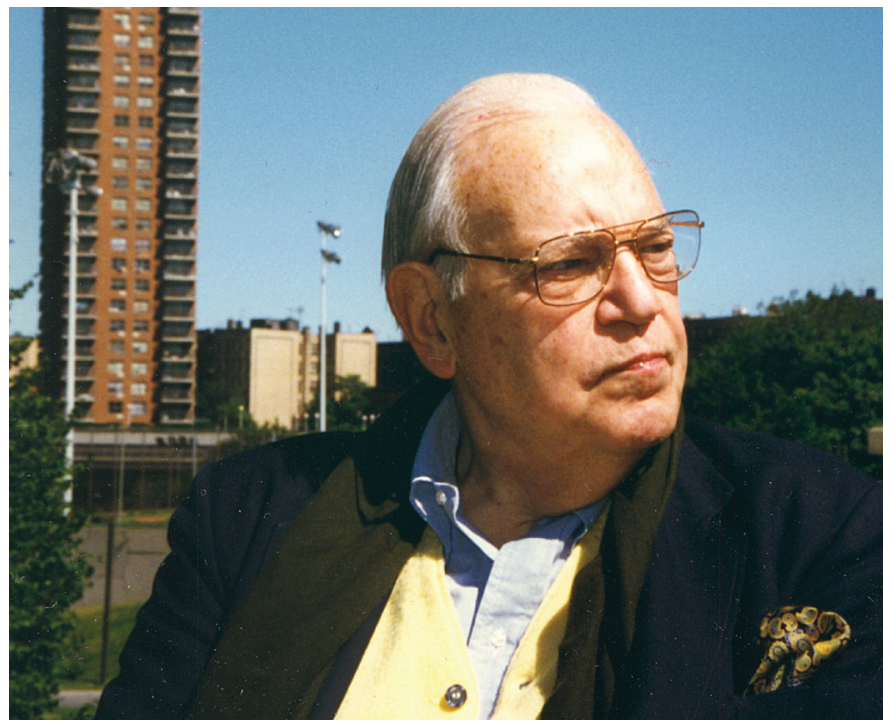

Fig. 3. Mel Moss, mid-1990s. 


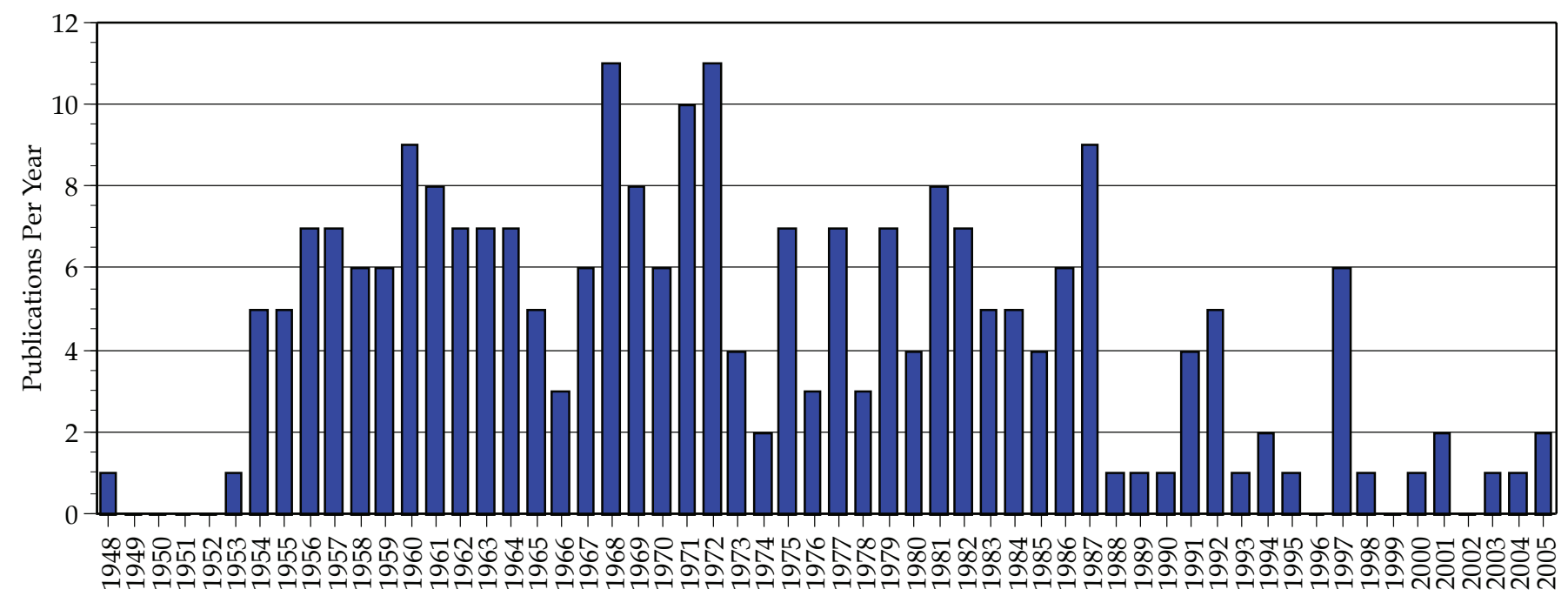

Fig. 5. Publications per year.

\section{Bibliography, Melvin L. Moss}

\section{8}

Moss ML. 1948. Restoration of facial contour. Dental Digest 54:506-514.

\section{3}

Levy BM, Rugh R, Lunin L, Chilton N, Moss ML. 1953. The effect of a single sub-acute $\mathrm{X}$-ray exposure to the fetus on skeletal growth; a quantitative study. J Morph 93:561-572.

Noback CR, Moss ML. 1953. The topology of the human premaxillary bone. Am J Phys Anthropol 11:181-188.

\section{4}

Carpenter MB, Noback CR, Moss ML. 1954. The anterior choroidal artery; its origins, course, distribution, and variations. AMA Arch Neurol Psychiatry 71:714-722.

Moss ML. 1954. Demonstration of the intrinsic vascular pattern of compact bone; a vital split-line technic. Am J Phys Anthropol 12:373-383.

Moss ML. 1954. Differential growth analysis of bone morphology. Am J Phys Anthropol 12:71-76.

Moss ML. 1954. Growth of the calvaria in the rat; the determination of osseous morphology. Am J Anat 94:333-361.

Moss ML. 1954. Vital staining of newly formed areas of compact bone with Chlorazol Fast Pink. Stain Tech 29:247-251.

\section{5}

Moss ML. 1955. Relative growth of the human fetal skeleton, cranial and postcranial. Ann NY Acad Sci 63:528-536.

Moss ML. 1955. Correlation of cranial base angulation with cephalic malformations and growth disharmonies of dental interest. N Y State Dent J 21:452-454.
Moss ML. 1955. Morphological changes in the growing rat skull following administration of cortisone acetate. Proc Soc Exp Biol Med 89:648-650.

Moss ML, Greenberg SN. 1955. Postnatal growth of the human skull base. Angle Orthod 25:77-84.

Moss ML, Noback CR, Robertson GG. 1955. Critical developmental horizons in human fetal long bones; correlated quantitative and histological criteria. Am J Anat 97:155-175.

\section{6}

Baer MJ, Moss ML. 1956. Differential growth of the rat skull. Growth 20:107-120.

Moss ML. 1956. Progress in anatomy. N Y State Dent J 22:76-77.

Moss ML. 1956. Dysostosis sphenoidalis as a characteristic of cleft palate malformations. Cleft Palate Bull 6:2-4.

Moss ML. 1956. Malformations of the skull base associated with cleft palate deformity. Plast Reconstr Surg 17:226234.

Moss ML, Greenberg S. 1956. Mesial movement of mandibular buccal dentition in treatment of Class II malocclusion. N Y State Dent J 22:460-462.

Moss ML, Noback CR. 1956. Differential growth of the human brain. J Comp Neurol 105:539-551.

Moss ML, Noback CR, Robertson GG. 1956. Growth of certain human fetal cranial bones. Am J Anat 98:191204.

\section{7}

Moss ML. 1957. Experimental alteration of sutural area morphology. Anat Rec 127:569-589.

Moss ML. 1957. Normal and abnormal velopharyngeal anatomy. Cleft Palate Bull 7:5-8.

Moss ML. 1957. Progress review: anatomy. N Y State Dent J 23:14-15. 


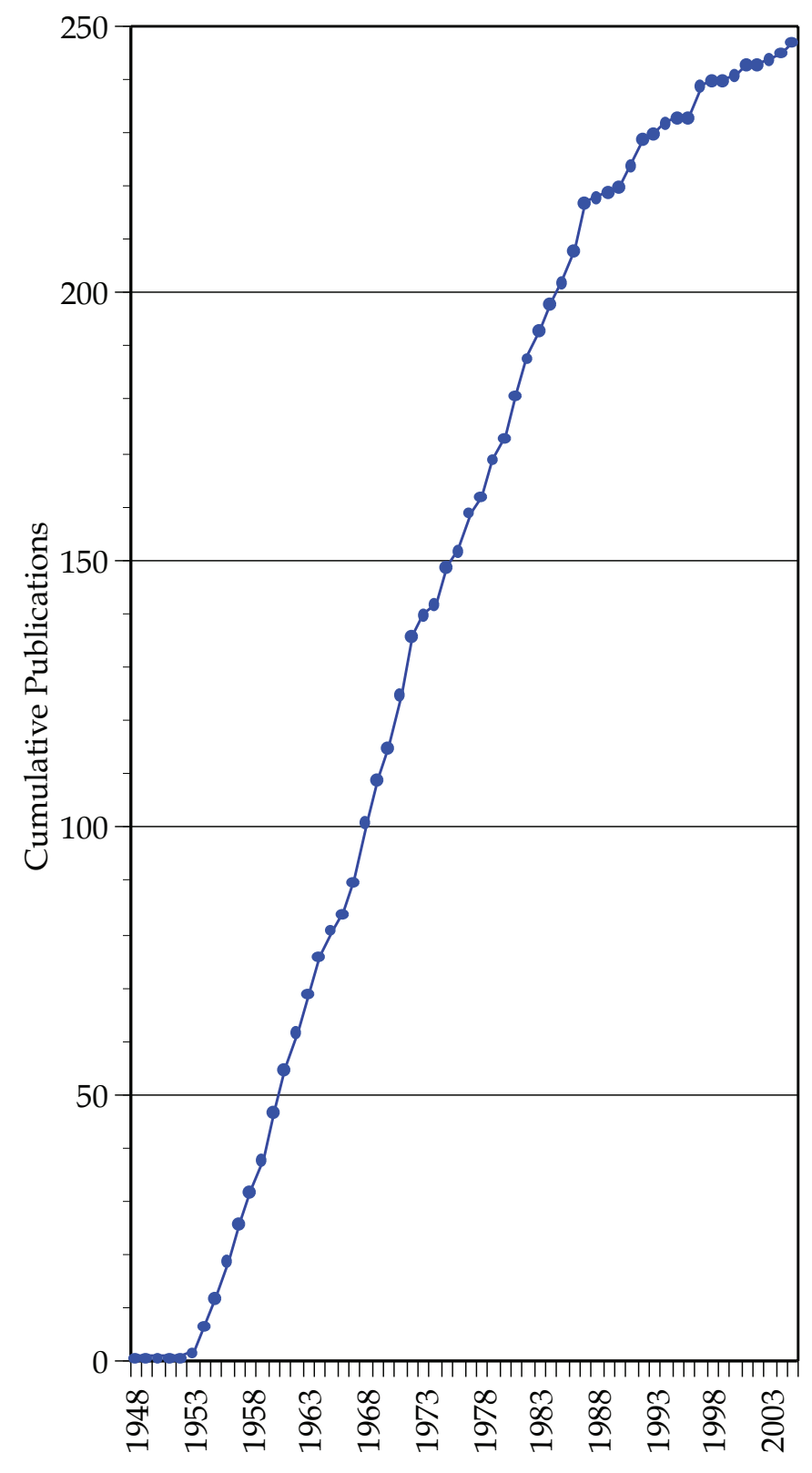

Fig. 5. Cumulative graph of publications.

Moss ML. 1957. Progress review: anatomy. N Y State Dent J 23:413-414.

Moss ML. 1957. Premature synostosis of the frontal suture in the cleft palate skull. Plast Reconstr Surg 20:199-205.

Moss ML. 1957. Synopsis of formation and repair of calcified tissues. N Y State Dent J 23:359-360.

Moss ML, Applebaum E. 1957. Differential growth analysis of vertebrate teeth. J Dent Res 36:644-651.

\section{8}

Moss ML. 1958. Bone graft substitutes. N Y State Dent J 24:353-354.
Moss ML. 1958. Extraction of an osteogenic inductor factor from bone. Science 127:755-756.

Moss ML. 1958. Fusion of the frontal suture in the rat. Am J Anat 102:141-165.

Moss ML. 1958. Rotations of the cranial components in the growing rat and their experimental alteration. Acta Anat (Basel) 32:65-86.

Moss ML. 1958. The pathogenesis of artificial cranial deformation. Am J Phys Anthropol 16:269-286.

Moss ML, Noback CR. 1958. A longitudinal study of digital epiphyseal fusion in adolescence. Anat Rec 131:19-32.

1959

Moss ML. 1959. Embryology, growth and malformation of the temporomandibular joint. In: Schwartz L, editor. Disorders of the temporomandibular joint. Philadelphia: WB Saunders, p 89-104.

Moss ML. 1959. Functional anatomy of the temporomandibular joint. N Y State Dent J 29:315-319.

Moss ML. 1959. Functional anatomy of the temporomandibular joint. In: Schwartz L, editor. Disorders of the temporomandibularjoint. Philadelphia: WB Saunders, $\mathrm{p}$ 73-88.

Moss ML. 1959. The pathogenesis of premature cranial synostosis in man. Acta Anat (Basel) 37:351-370.

Moss ML, CrikelairGF.1959. Progressivefacial hemiatrophy following cervical sympathectomy in the rat. Arch Oral Biol 1:254-258.

Moss ML, Greenberg SN, Noback CR. 1959. Developmental migration of mandibular buccal dentition in man. Angle Orthod 29:169-176.

1960

Gorlin RJ, Chaudhry AP, Moss ML. 1960. Craniofacial dysostosis, patent ductus arteriosus, hypertrichosis, hypoplasia of labia majora, dental and eye anomalies a new syndrome? J Pediatr 56:778-785.

Moss ML. 1960. A functional analysis of human mandibular growth. Am J Prosthet Dent 10:1149-1160.

Moss ML. 1960. A reevaluation of the dental status and chronological age of the Tepexpan remains. Am J Phys Anthropol 18:71-72.

Moss ML. 1960. Experimental induction of osteogenesis. In: Sognnaes RF, editor. Calcification in biological systems. Publication 64. Washington: AAAS, p 323-348.

Moss ML. 1960. Inhibition and stimulation of sutural fusion in the rat calvaria. Anat Rec 136:457-467.

Moss ML, CrikelairGF.1960.Progressivefacial hemiatrophy following cervical sympathectomy in the rat. Arch Oral Biol 1:254-258.

Moss ML, Posner AS. 1960. X-ray diffraction study of acellular teleost bone. Nature 188:1037-1038.

Moss ML, Young RW. 1960. A functional approach to craniology. Am J Phys Anthropol 18:281-292.

Noback CR, Moss ML, Lesczynska E. 1960. Digital epiphyseal fusion of the hand in adolescence: a longitudinal study. Am J Phys Anthropol 18:13-18. 


\section{1}

Burstone CJ, Kraus BS, Moss ML, Weinstein S. 1961. Report on the symposium on growth. Am J Orthod 47:52-56.

Moss ML. 1961. Extrinsic determination of sutural area morphology in the rat calvaria. Acta Anat (Basel) 44:263-272.

Moss ML. 1961. Functional analysis of human mandibular growth. Am J Prosth Dent 10:1149-1159.

Moss ML. 1961. Osteogenesis of acellular teleost fish bone. Am J Anat 108:99-110.

Moss ML. 1961. Rotation of the otic capsule in bipedal rats. Am J Phys Anthropol 19:301-307.

Moss ML. 1961. Studies of the acelluar bone of teleost fish. I. Morphological and systematic variations. Acta Anat (Basel) 46:343-362.

Moss ML. 1961. The initial phylogenetic appearance of bone: an experimental hypothesis. Trans N Y Acad Sci 23:495-500.

Posner A, Moss ML. 1961. X-ray diffraction of acellular teleost bone. Nature 188:1037-1038.

\section{2}

Crikelair G, Bom A, Luban J, Moss ML. 1962. Early orthodontic movement of cleft maxillary segments prior to cleft lip repair. Plast Reconstr Surg 30:426-440.

Crikelair GF, Moss ML, Khuri A. 1962. Facial hemiatrophy. Plast Reconstr Surg 29:5-13.

Lavine LS, Isenberg HD, Moss ML. 1962. Intracellular calcification in a coccolithophorid. Nature 196:78.

Lavine LS, Moss ML, Noback CR. 1962. Digital epiphyseal fusion in adolescence. A longitudinal study. J Pediatr 61:571-575.

Moss ML. 1962. Studies of the acellular bone of teleost fish. II. Response to fracture under normal and acalcemic conditions. Acta Anat (Basel) 48:46-60.

Moss ML. 1962. Studies of the acellular bone of teleost fish. 3. Intraskeletal heterografts in the rat. Acta Anat (Basel) 49:266-280.

Moss ML. 1962. The functional matrix. In: Kraus BS, Riedel $\mathrm{R}$, editors. Vistas in Orthodontics. Philadelphia: Lea \& Febiger, p 85-98. [Reprinted in Ortodoncia Clinica (Barcelona) 1998:1(3):129-138.]

\section{3}

Isenberg HD, Lavine LS, Moss ML, Kupferstein D, Lear PE. 1963. Calcification in a marine coccolithophorid. Ann N Y Acad Sci 109:49-64.

Ju DMC, Moss ML, Crikelair GF. 1963. Effect of radiation on the development of facial structures in retinoblastoma cases. Am J Surg 106:807-815.

Moss ML. 1963. Morphological variations of the crista galli and medial orbital margin. Am J Phys Anthropol 21:159-164.

Moss ML. 1963. The biology of acellular teleost bone. Ann N Y Acad Sci 109:337-350.

Moss ML. 1963. The functional anatomy of the oral cavity and the pharynx. In: Rehabilitation of the oral-facialspeech handicapped: a symposium. Lancaster, PA: Lancaster Cleft Palate Clinic.
Moss ML, Applebaum E. 1963. The fibrillar matrix of marsupial enamel. Acta Anat (Basel) 53:289-297.

Moss ML, Freilich M. 1963. Studies of the acellular bone of teleost fish. IV. Inorganic content of calcified tissues. Acta Anat (Basel) 55:1-8.

\section{4}

Isenberg HD, Lavine LS, Moss ML, Shamos MH, Weisfellner H. 1964. Calcium45 turnover in a mineralizing cocclithophorid protozoan. J Protozool 11:531-534.

Moss ML. 1964. Development of cellular dentin and lepidosteal tubules in the bowfin, Amia calva. Acta Anat (Basel) 58:333-354.

Moss ML. 1964. Differential mineralization of growing human and rat cranial bones. Am J Phys Anthropol 22:155-161.

Moss ML. 1964. The bony nasopharynx. Am J Phys Anthropol 22:193.

Moss ML. 1964. The phylogeny of mineralized tissues. International Rev Gen Exp Zool 1:297-331.

Moss ML. 1964. Vertical growth of the human face. Am J Orthod 50:359-376.

Moss ML, Jones SJ, Piez KA. 1964. Calcified ectodermal collagens of shark tooth enamel and teleost scale. Science 145:940-942.

\section{5}

Moss ML. 1965. Acellular bone. In: Yearbook of science and technology. New York: McGraw-Hill, p 135-136.

Moss ML. 1965. Calcification. In: Horowitz S, editor. The nature of orthodontic diagnosis. St. Louis: CV Mosby.

Moss ML. 1965. Hypertelorism and cleft palate deformity. Acta Anat (Basel) 61:547-557.

Moss ML.1965. Studies of the acellular bone of teleost fish. V. Histology and mineral homeostasis of fresh-water species. Acta Anat (Basel) 60:262-276.

Moss ML. 1965. The veloepiglottic sphincter and obligate nose breathing in neonate. J Pediatrics 67:330-331.

1966

Moss ML, Chase PS. 1966. Morphology of Liberian Negro deciduous teeth I. Odontometry. Am J Phys Anthropol 24:215-229.

Moss ML, Chase PS. 1966. Morphology of Liberian Negro deciduous teeth. II. Arch dimensions and occlusion. Am J Phys Anthropol 25:261-275.

Moss ML, Murchison E. 1966. Calcified anal teeth and pharyngeal ring in a holothurian (Actinopyga mauritania). Acta Anat 64:446-461.

\section{7}

Moss ML. 1967. Dermal sclerifications. In: Gans C, Williams E, D'a Bellairs A, editors. Biology of reptilia. New York: Academic Press.

Moss ML, Chase PS, Howes RI. 1967. Comparative odontometry of permanent post-canine dentition of American Whites and Negroes. Am J Phys Anthropol 27:125-142.

Moss ML, Chase PS, Kameros S. 1967. Trabecular bone structure of post-canine alveolar processes in adult American Whites and Negroes. Acta Anat 67:399-423. 
Moss ML, Greenberg SN. 1967. Functional cranial analysis of the human maxillary bone. I. Basal bone. Angle Orthod 37:151-164.

Moss ML, Kermack KA. 1967. Enamel structure in two Triassic mammals. J Dent Res 46:745-747.

Moss ML, Meehan MM. 1967. Sutural connective tissues in the test of an echinoid: Arbacia punctulata. Acta Anat (Basel) 66:279-304.

\section{8}

Moss ML. 1968. A theoretical analysis of the functional matrix. Acta Biotheor 18:195-202.

Moss ML. 1968. Comparative anatomy of vertebrate dermal bone and teeth. I. The epidermal co-participation hypothesis. Acta Anat (Basel) 71:178-208.

Moss ML. 1968. Facial growth: the functional matrix concept. In: Grabb WC, Rosenstein SN, Brock KR, eds. Cleft lip and palate. Boston: Little, Brown and Company, p 97-107.

Moss ML. 1968. Functional cranial analysis of mammalian mandibular ramal morphology. Acta Anat (Basel) 71:423-447.

Moss ML. 1968. The origin of vertebrate calcified tissues. In: Ørvig T, editor. 4th Nobel Symposium. Stockholm: Almqvist \& Wiksell, p 359-371.

Moss ML. 1968. The primacy of functional matrices in orofacial growth. Dent Pract Dent Rec 19:65-73.

Moss ML, Bromberg BE, Song IC, Eisenman G. 1968. The passive role of nasal septal cartilage in mid-facial growth. Plast Reconstr Surg 41:536-542.

Moss ML, Chase P, Kameros J. 1968. Trabecular bone structure of post-canine alveolar processes in adult American whites and negroes. Acta Anat (Basel) 67:399423.

Moss ML, Meehan M. 1968. Growth of the echinoid test. Acta Anat (Basel) 69:409-444.

Moss ML, Rankow RM. 1968. The role of the functional matrix in mandibular growth. Angle Orthod 38:95-103.

Moss ML, Simon MR. 1968. Growth of the human mandibular angular process: a functional cranial analysis. Am J Phys Anthropol 28:127-138.

1969

Isenberg HD, Moss ML, Lavine LS. 1969. An introduction to the comparative morphology of mineralized tissues. Curr Pract Orthop Surg 4:202-237.

Moss ML.1969. Comparative histology of dermal sclerifications in reptiles. Acta Anat (Basel) 73:510-533.

Moss ML. 1969. Functional cranial analysis of the mandibular angular cartilage in the rat. Angle Orthod 39:209-214.

Moss ML. 1969. Phylogeny and comparative anatomy of oral ectodermal-ectomesenchymal inductive interactions. J Dent Res 48:732-737.

Moss ML. 1969. The differential roles of periosteal and capsular functional matrices in oro-facial growth. Rep Congr Eur Orthod Soc 1969:193-205.
Moss ML. 1969. The evolution of mammalian dental enamel. Paper no. 2360. American Museum Novitates, 39 pages.

Moss ML, Salentijn L. 1969. The capsular matrix. Am J Orthod 56:474-490.

Moss ML, Salentijn L. 1969. The primary role of functional matrices in facial growth. Am J Orthod 55:566-577.

\section{0}

Moss ML. 1970. Enamel and bone in shark teeth: with a note on fibrous enamel in fishes. Acta Anat (Basel) 77:161-187.

Moss ML. 1970. Role of the functional matrix in growth. J Maxillofac Orthopedics 3:13-18.

Moss ML. 1970. The primacy of functional matrices in orofacial growth. Trans $\mathrm{Br}$ Soc Study Orthod 1968/1969:107-115.

Moss ML. 1970. The role of muscular functional matrices in development and maintenance of occlusion. Bull Pac Coast Soc Orthod 45:29-30.

Moss ML, Meehan MA. 1970. Functional cranial analysis of the coronoid process in the rat. Acta Anat (Basel) 77:11-24.

Moss ML, Salentijn L. 1970. The logarithmic growth of the human mandible. Acta Anat (Basel) 77:341-360.

\section{1}

Lavine LS, Lustrin I, Shamos MH, Moss ML. 1971. The influence of electric current on bone regeneration in vivo. Acta Orthop Scand 42:305-314.

Moss ML. 1971. Facial growth. In: Grabb WC, Rosenstein SW, Bzoch KR, editors. Cleft lip and palate. Boston: Little Brown and Company, p 97-108.

Moss ML. 1971. Functional cranial analysis and the functional matrix. Am Speech Hear Assoc Rep 6:5-18. [Reprinted: Int J Orthod 17, March 1979]

Moss ML. 1971. Neurotrophic processes in orofacial growth. J Dent Res 50:1492-1494.

Moss ML. 1971. Ontogenetic aspects of craniofacial growth. In: Moyers RE, Krogman WM, editors. Craniofacial growth in man. Oxford: Pergamon Press, p 109-124.

Moss ML. 1971. The skeletal system: a physiological and biomechanical perspective. In: Waterman AJ, editor. Chordate structure and function. New York: Macmillan Company.

Moss ML, Salentijn L. 1971. Differences between the functional matrices in anterior open-bite and in deep overbite. Am J Orthod 60:264-280.

Moss ML, Salentijn L. 1971. The compensatory role of the condylar cartilage in mandibular growth: theoretical and clinical implications. Dtsch Zahn Mund Kieferheilkd Zentralbl Gesamte 56:5-16.

Moss ML, Salentijn L. 1971. The unitary logarithmic curve descriptive of human mandibular growth. Acta Anat (Basel) 78:532-542.

Salentijn L, Moss ML. 1971. Morphological attributes of the logarithmic growth of the human face: gnomonic growth. Acta Anat (Basel) 78:185-199. 
1972

Moss ML. 1972. An introduction to the neurobiology of oro-facial growth. Acta Biotheor 21:236-259.

Moss ML. 1972. Bone induction. Annu Meet Am Inst Oral Biol, p 49-58.

Moss ML. 1972. Functional cranial analysis and the functional matrix. In: Schumacher G-H, editor. Morphology of the maxillo-mandibular apparatus. Leipzig: VEB G. Thieme, p 160-165.

Moss ML. 1972. New research objectives in craniofacial morphogenesis. Acta Morphol Neerl Scand 10:103-110.

Moss ML. 1972. The non-existent hinge axis. Annu Meet Am Inst Oral Biol, p 59-66.

Moss ML. 1972. The regulation of skeletal growth. In: Goss RJ, editor. The regulation of organ and tissue growth. New York: Academic Press, p 127-142.

Moss ML. 1972. The role of intrinsic and extrinsic factors in the regulation of skeletal growth. Annu Meet Am Inst Oral Biol, p 67-78.

Moss ML.1972. The vertebrate dermis and the integumental skeleton. Am Zool 12:27-34.

Moss ML. 1972. Twenty years of functional cranial analysis. Am J Orthod 61:479-485.

Moss ML, Meehan MA, Salentijn L. 1972. Transformative and translative growth processes in neurocranial development of the rat. Acta Anat (Basel) 81:161-182.

Moss ML, Meehan MM, Salentijn L. 1972. Transformative and translative growth processes in neurocranial development in the rat. Acta Anat 81:161-182.

\section{3}

Moss ML. 1973. A functional cranial analysis of primate craniofacial growth. In:Montagna W, editor.Symposium IV. Int Congr Primat 3:191-208.

Moss ML. 1973. Funktionelle Schädelanalyse und die Funktionelle Matrix. Fortschr Kieferorthrop 34:48-63.

Salentijn L, Moss ML. 1973. Enamel (tooth). In: Gray P, editor. Encyclopedia of microscopy and microtechnique. New York: van Nostrand Rheinhold Company.

Simon MR, Moss ML. 1973. A functional cranial analysis of human sigmoid notch form. Acta Anat (Basel) 85:133144.

\section{4}

Moss ML. 1974. Studies on dentin. I. Mantle dentin. Acta Anat (Basel) 87:481-507.

Srour RK, Crikelair GF, Moss ML. 1974. Neurotrophism in relation to muscle and nerve grafts in rats. Surg Forum 25:508-511.

\section{5}

Moss ML. 1975. A functional cranial analysis of centric relation. Dent Clin North Am 19:431-442.

Moss ML. 1975. Functional anatomy of cranial synostosis. Childs Brain 1:22-33.

Moss ML. 1975. New studies of cranial growth. Birth Defects Orig Artic Ser 11:283-295.
Moss ML. 1975. Neurotrophic regulation of craniofacial growth. In: McNamara JA Jr, ed. Control mechanisms in craniofacial growth. Monograph 3, Craniofacial Growth Series. Ann Arbor: Center for Human Growth and Development, University of Michigan, p 25-50.

Moss ML. 1975. The effect of rhombencephalic hypoplasia on posterior cranial base elongation in rodents. Arch Oral Biol 20:489-492.

Moss-Salentijn L, Moss ML. 1975. Studies on dentin 2. transient vasodentin in the incisor teeth of a rodent (perognathus longimembris). Acta Anat (Basel) 91:386404.

Person P, Eversole LR, Shklar G, Johnson LC, Moss ML. 1975. The effects of cosmic particle radiation on pocket mice aboard Apollo XVII: appendix II. Evaluation of oral, dental, and skeletal tissues. Aviat Space Environ Med 46(4 Sec 2):634-638.

\section{6}

Moss ML. 1976. Experimental alteration of basisynchondrosal cartilage growth in rat and mouse. In: Bosma J, editor. Symposium on development of the basicranium. DHEW Publication No.(NIH) 76-989. Washington, DC: U.S. Government Printing Office, $\mathrm{p}$ 541-575.

Moss ML. 1976. The role of the nasal septal cartilage in midfacial growth. In: McNamara JA Jr, editor. Control mechanisms in craniofacial growth. Monograph 6, Craniofacial Growth Series. Ann Arbor: Center for Human Growth and Development, University of Michigan, p 169-204.

Moss-Salentijn L, Moss ML. 1976. Developmental and functional anatomy. In: Rankow R, Polayes IM, editors. Diseases of the salivary glands. Philadelphia: WB Saunders.

\section{7}

MelsenB,MossML.1977.Theeffectofmethylazoxymethanol on growth of the spheno-occipital synchondrosis in rats. Acta Anat (Basel) 97(3):300-306.

Moss ML. 1977. A functional analysis of fusion of the tibia and fibula in the rat and mouse. Acta Anat (Basel) 97:321-332.

Moss ML. 1977. Skeletal tissues in the shark. Am Zool 17:335-342.

Moss ML, Feliciano W. 1977. A functional analysis of the fenestrated maxillary bone of the rabbit (Oryctolagus cuniculus). Anat Histol Embryol 6:167-187.

Moss M, Pilcher W. 1977. Epigenetic regulation of nasal conchal morphogenesis in the rat: a preliminary study. In: McNamara JA Jr, editor. The biology of occlusal development. Monograph 7, Craniofacial Growth Series. Ann Arbor: Center for Human Growth and Development, University of Michigan, p 293-312.

Moss ML,Moss-SalentijnL.1977. Analysis of developmental processes possibly related to human dental sexual dimorphism in permanent and deciduous canines. Am J Phys Anthropol 46:407-413. 
Moss-Salentijn L, Moss ML. 1977. Effects of occlusal attrition and continuous eruption on odontometry of rat molars. Am J Phys Anthropol 47:403-407.

\section{8}

Moss ML. 1978. Analysis of developmental processes possibly related to human dental sexual dimorphism. In: Butler PM, Joysey KA, editors. Development, function and evolution of teeth. London: Academic Press Inc., p 135-148.

Moss ML, Moss-Salentijn L. 1978. The muscle-bone interface: an analysis of a morphological boundary. In: Carlson DS, McNamara JAJr, editors. Muscle adaptation in the craniofacial region. Monograph 8, Craniofacial Growth Series. Ann Arbor: Center for Human Growth and Development, University of Michigan, p 39-72.

Moss ML, Vilmann H. 1978. Studies on orthocephalization of the rat head. I. A model system for the study of adjustive cranical growth processes. Gegenbaurs Morphol Jahrb 124:559-579.

\section{9}

Chiu DT, Crikelair GF, Moss ML. 1979. Epigenetic regulation of the shape and position of the auricle in the rat. Plast Reconstr Surg 63:411-417.

Moss ML. 1979. Functional cranial analysis and the functional matrix. Int J Orthod 17:21-31.

Moss ML. Gross anatomy. 1979. In: Boucher L, editor. A comprehensive review of dentistry. Philadelphia: WB Saunders.

Moss ML, Moss-Salentijn L. 1979. Mineral metabolism and bone. Chemical Zool 17:77-102.

Vilmann H, Moss ML. 1979. Studies on orthocephalization. 2. Flexions of the rat head in the period between 14 and 60 days after gestation. Gegenbaurs Morphol Jahrb 125:572-582.

Vilmann H, Moss ML. 1979. Studies on orthocephalization of the rat head. 3. Spatial position of the lateral semicircular canal in 14-60 day-old rat heads. Scand J Dent Res 87:171-177.

Vilmann H, Moss ML. 1979. Spatial position of the lateral semicircular canal in 14-60-day-old rat heads. Scand J Dent Res 87:171-177.

\section{0}

Moss ML. 1980. The design of bones. In: Owen R, Goodfellow JW, Bullough PG, editors. Scientific foundations of orthopaedics and the surgery of trauma. London: William Heinemann.

Moss ML, Skalak R, Dasgupta G, Vilmann H. 1980. Space, time, and space-time in craniofacial growth. Am J Orthod 77:591-612.

Vilmann H, Kirkeby S, Moss ML. 1980. Studies on orthocephalization. IV. Differential growth of the sphenooccipital synchondosis in the rat. Anat Anz 148:97-104.

Vilmann H, Moss ML. 1980. Studies on orthocephalization. V. peripheral positional stability of the rat cranial frame in the period between 14 and 150 days. Acta Anat (Basel) 107:330-335.

\section{1}

Melsen B, Melsen F, Moss ML. 1981. Postnatal development of the nasal septum studied on human autopsy material. In Carlson DS, ed. Craniofacial Biology. Monograph 10, Craniofacial Growth Series. Ann Arbor: Center for Human Growth and Development, University of Michigan, p 127-144.

Moss ML. 1981. A functional analysis of palatal and midfacial growth. In: Kehrer B, Slongo T, Bettex M, Graf B, editors. Late results of treatment in cleft lip and palate. Bern: Hans Huber, p 73-81.

Moss ML. 1981. Genetics, epigenetics, and causation. Am J Orthod 80:366-375.

Moss ML, Skalak R, Moss-Salentijn L, Dasgupta GM, Vilmann H, Mehta P. 1981. The allometric center: the biological basis of an analytical model of craniofacial growth. Proc Finn Dent Soc 77:119-128.

Moss ML, Vilmann H, Dasgupta G, Skalak R. 1981. Craniofacial growth in space-time. In: Carlson DS, Ribbens KA, editors. Craniofacial Biology. Monograph 10, Craniofacial Growth Series. Ann Arbor: Center for Human Growth and Development, University of Michigan, p 61-82.

Vilmann H, Moss ML. 1981. Studies on orthocephalization. 6. Flexions of the rat head in the period between 1 day before gestation and 14 days after gestation. Gegenbaurs Morphol Jahrb 127:176-187.

Vilmann H, Moss ML. 1981. Studies on orthocephalization. VII. Behavior of the rat cranial frame in the period between 1 day before birth to 14 days after birth. Acta Anat (Basel) 109:157-160.

Vilmann H, Moss ML, Skalak R, Vilmann O. 1981. Spacetime presentations of the shell of the bivalved mollusk Cardium edule. Am J Orthod 80:417-428.

\section{2}

Moss ML. 1982. The dialectics of craniofacial growth research: it is time for a new synthesis. In: McNamara JA Jr, Carlson DS, Ribbens KA, editors. The effect of surgical intervention on craniofacial growth. Ann Arbor: Center for Human Growth and Development, University of Michigan, p 373-382.

Moss ML. 1982. The logarithmic spiral and allometry as expressions of odontogenic thermodynamics. In: Kurtén B, editor. Teeth: form, function and evolution. New York: Columbia University Press, p 75-89.

Moss ML. 1982. The functional matrix: Functional cranial components. In: Kraus BS, Reidel R, editors. Vistas in orthodontics. Philadelphia: Lea and Febiger, p 85-98.

Moss ML, Moss-Salentijn L, Vilmann H, Newell-Morris L. 1982. Neuro-skeletal topology of the primate basicranium: its implications for the "fetalization hypothesis." Gegenbaurs Morphol Jahrb 128:58-67.

Moss ML, Shinozuka M, Skalak R. 1982. The application of spectral analysis of random processes to the study of adjustive cranial skeletal growth. Prog Clin Biol Res 101:411-421. 
Moss ML, Shinozuka M, Skalak R. 1982. The application of spectral analysis of random processes to the study of adaptive cranial skeletal growth. In: Dixon A, Sarnat $B$, editors. Factors and mechanisms influencing bone growth. New York: Alan R. Liss, p 411-421.

Skalak R, Dasgupta G, Moss ML, Otten E, Dullemeijer P, Vilmann H. 1982. Analytical description of growth. J Theor Biol 94:555-577.

\section{3}

Moss ML. 1983. Beyond roentgenographic cephalometrywhat? Am J Orthod 84:77-79.

Moss ML. 1983. The functional matrix concept and its relationship to temporomandibular joint dysfunction and treatment. Dent Clin North Am 27:445-455.

Moss ML, Moss-Salentijn L. 1983. Vertebrate cartilages. In: Hall BK, editor. Cartilage. Vol. 1. New York: Academic Press, $\mathrm{p}$ 1-30.

Moss ML, Skalak R, Shinozuka M, Patel H, Moss-Salentijn L, Vilmann H, Mehta P. 1983. Statistical testing of an allometric centered model of craniofacial growth. Am J Orthod 83:5-18.

Patel H, Moss ML, Skalak R. 1983. Compatability considerations for volumetric growth tensors. Am Soc Mech Eng AMD 56:149-151.

\section{4}

Moss ML. 1984. Cephalometrics - the promise that failed. In: Khan Ata UR, Moss ML, editors. Emerging dentistry. Pakistan: Rawalpindi.

Moss ML. 1984. The functional matrix hypothesis: its explanatory role in problems of craniofacial form and growth. In: Khan Ata UR, Moss ML, editors. Emerging dentistry. Pakistan: Rawalpindi.

Moss ML, Skalak R, Patel H, Shinozuka M, Moss-Salentijn L, Vilmann H. 1984. An allometric network model of craniofacial growth. Am J Orthod 85:316-332.

Moss ML, Skalak R, Shinozuka M, Patel H, MossSalentijn L, Vilmann H, Mehta P. 1984. The testing of an allometric center model of craniofacial growth. Z Morphol Anthropol 74:295-313.

Shinozuka M,Tsurui A, Naganuma T, Moss ML, MossSalentijn L. 1984. A stochastic-mechanical model of longitudinal bone growth. J Theor Biol 108:413-436.

\section{5}

Moss ML. 1985. The application of the finite element method to the analysis of craniofacial growth and form. Acta Morphol Neerl Scand 23:337-356.

Moss ML. 1985. The functional matrix hypothesis and epigenetics.In:GraberTM, editor.Physiologic principles of functional appliances. St. Louis: CV Mosby.

Moss ML, Skalak R, Patel H, Sen K, Moss-Salentijn L, Shinozuka M, Vilmann H. 1985. Finite element method modeling of craniofacial growth. Am J Orthod 87:453472.

Vilmann H, Moss ML. 1985. Studies on orthocephalization. 8. Behaviour of the visceral part of the rat head in the period between 7 and 60 days after gestation. Gegenbaurs Morphol Jahrb 131:329-335.

\section{6}

Moss ML. 1986. Newer analytical models of craniofacial growth. Acta Leopoldina NF 58:17-25.

Moss ML. 1986. [New analytical concepts of craniofacial growth]. Inf Dent 68:193-200. [French.]

Moss ML. 1986. The application of the finite element method to the analysis of cephalic growth. Ann Hum Biol 12 (Suppl.): 9.

Moss ML.1986. The application of the finite element method to the analysis of cephalic growth. In: Demirjian A, editor. IV International Congress of Auxology. London: Taylor and Francis 12:127-140.

Moss ML, Moss-Salentijn L, Skalak R. 1986. Finite element modeling of craniofacial growth and development. In: Graber LW, editor. Orthodontics: state of the art, essence of the science. St. Louis: CV Mosby, p 143-168.

Skalak R, Moss ML. 1986. Analysis of growth and form. Adv Bioengineer ASME 1985:1-2.

\section{7}

Anderson OR, Moss ML, Skalak R. 1987. The cytoskeleton and biomineralized supportive structures in radiolaria. In: Bareiter-Halin J, Anderson OR, Reif W, editors. Cytomechanics. Heidelberg: Springer Verlag, p 200211.

Chowdary RP, Berkhower AS, Moss ML, Hugo NE. 1987. Fluorocarbon and enhancement of skin flap survival in rats. Plast Reconstr Surg 79:98-101.

Chowdary RP, Moss ML, Hugo NE. 1987. Use of computer analysis in flap research. Ann Plast Surg 18:261-264.

Moss ML. 1987. Integration of the functional matrix hypothesis and the finite element method: a new paradigm for the analysis of craniofacial growth. Le Journaldel'Edgewise. CollegeEuropéend'Orthodontie, Paris 15:7-54. [translated in French]

Moss ML, Pucciarelli HM, Moss-Salentijn L, Skalak R, Bose A, Goodall C, Sen K, Morgan B, Winick M. 1987. Effects of pre-weaning undernutrition on 21 day-old male rat skull form as described by the finite element method. Gegenbaurs Morphol Jahrb 133:837-868.

Moss ML, Vilmann H, Moss-Salentijn L, Sen K, Pucciarelli HM, Skalak R. 1987. Studies on orthocephalization: growth behavior of the rat skull in the period 13-49 days as described by the finite element method. Am J Phys Anthropol 72:323-342.

Moss-Salentijn L, Moss ML, Shinozuka M, Skalak R. 1987. Morphological analysis and computer-aided, three dimensional reconstruction of chondrocytic columns in rabbit growth plates. J Anat 151:157-167.

Pucciarelli H, Moss ML, Skalak R, Moss-Salentijn L, Sen K, Vilmann H. 1987. Aplicación del método de los elementos finitos en estudios de diferenciación craneofacial. Rev del Museo de la Plata (ns) Sección Antropología 9:1-20.

Vilmann H, Moss ML. 1987. Studies on orthocephalization. 10. Behaviour of the visceral part of the rat head during the first 14 days after gestation. Gegenbaurs Morphol Jahrb 133:739-745. 


\section{8}

Moss ML. 1988. Finite element comparison of murine mandibular form differences. J Craniofac Genet Develop Biol 8:3-20.

\section{9}

Vilmann H, Kirkeby S, Moss ML. 1989. Skull development in the muscular dystrophic mouse. Eur J Orthod 11:206213.

\section{0}

Campbell S, Tattelbaum A, Rosenberg M, Chowdary R, Moss ML, Hugo N. 1990. Fluorometric analysis of an attempt to reclaim ischemic flaps in rats with Flusol. Plast Reconstr Surg 84:484-491.

1991

Moss ML. 1991. Alternate mechanisms of bone remodeling: their representation in a connected cellular network model. Annals Biomed Engineer 19:636.

Moss ML. 1991. Bone as a connected cellular network: testing and modeling. In: Ross G, editor. Topics in biomedical engineering. Oxford: Pergamon Press, $\mathrm{p}$ 117-119.

Cowin SC, Moss-Salentijn L, Moss ML. 1991. Candidates for the mechanosensory system in bone. J Biomech Eng 113:191-197.

Tanne K, Hirano Y, Sakuda M, Moss ML. 1991. Finite element method modeling of mandibular growth. J Osaka Univ Dent School 41:73-84.

\section{2}

Campbell SP, Moss ML, Hugo N. 1992. When does a random flap die? Plast Reconstr Surg 89:718-721.

Dasgupta G, McAlarney M, Goodall C, Moss-Salentijn L, Moss ML. 1992. Form comparison without anatomical landmarks. Engineer Mech Proceed, EM Div/ASCE. College Station Texas, 5/24-27/92, p 976-979.

McAlarney ME, Dasgupta G, Moss ML, Moss-Salentijn L. 1992. Anatomical macroelements in the study of craniofacial rat growth. J Craniofac Genet Dev Biol 12:3-12.

McAlarney M, Dasgupta G, Moss ML, Moss-Salentijn L. 1992. Boundary macroelements and finite elements in biological morphometrics: a preliminary computational comparison. In: Held KD, Brebbia CA, Cikowski RD, editors. Computers in Biomedicine. Southhampton: Computational Mechanics Publications, p 61-74.

McAlarney M, Moss-Salentijn L, Moss ML, Basra M. 1992. Finite/macroelement meshes in neural rat growth. Engineer Mech Proceed, EM Div/ASCE. College Station Texas, 5/24-27/92, p 960-963.

\section{3}

Hammond AB, Smahel Z, Moss ML. 1993. Finite element method analysis of craniofacial morphology in unilateral cleft lip and palate prior to palatoplasty. J Craniofac Genet Dev Biol 13:47-56.

\section{4}

Cangialosi TJ, Moss ML, McAlarney ME, Nirenblatt BD, Yuan M. 1994. An evaluation of growth changes and treatment effects in Class II, division 1 malocclusion with conventional roentgenographic cephalometry and finite element method analysis. Am J Orthod Dentofacial Orthop 105:153-160.

Moss ML. 1994. Advances in finite element modeling of cephalic growth: the integration of macroelement and boundary element method with the functional matrix hypothesis. J Japan Orthod Soc 53:357-366.

\section{5}

Moss ML.1995. Growth and development of the craniofacial complex: an epigenetic viewpoint. In: Goodrich JT, Hall CD, editors. Craniofacial anomalies: growth and development from a surgical perspective. New York: Thieme Medical Publishers, Inc., p 1-7. 1997

Moss ML. 1997. The functional matrix hypothesis revisited. 1. The role of mechanotransduction. Am J Orthod Dentofacial Orthop 112:8-11.

Moss ML. 1997. The functional matrix hypothesis revisited. 2. The role of an osseous connected cellular network. Am J Orthod Dentofacial Orthop 112:221-226.

Moss ML. 1997. The functional matrix hypothesis revisited. 3. The genomic thesis. Am J Orthod Dentofacial Orthop 112:338-342.

Moss ML. 1997. The functional matrix hypothesis revisited. 4. The epigenetic antithesis and the resolving synthesis. Am J Orthod Dentofacial Orthop 112:410-417.

Moss ML, Cowin SC. 1997. Mechanosensory mechanisms in bone. In: Lanza R, Chick W, editors. Principles of tissue engineering. Austin, TX: R G Landes Comp, p 645-659.

Moss-Salentijn L, Moss ML, Yuan M. 1997. The ontogeny of mammalian enamel. In: von Koenigswald W, Sander PM, editors. Tooth enamel microstructure. Rotterdam: Balkema, p 5-30.

\section{8}

Moss ML. 1998. La Matriz Funcional. Ortodoncia Clinica (Barcelona) 1:129-138. [Reprint of Moss ML: The functional matrix. Vistas in orthodontics, p 85-98, Philadelphia 1962, Lea \& Febiger.]

\section{0}

Cowin SC, Moss ML. 2000. Mechanosensory mechanisms in bone. In: Lanza R, Langer R, Vacanti J, editors. Principles of tissue engineering, second ed. San Diego: Academic Press, p 723-737.

\section{1}

CowinSC, Moss ML. 2001. Mechanosensory mechanisms in bone. In: Cowin SC, editor. Bone mechanics handbook, second ed. Boca Raton: CRC Press, p 1-17.

Takeshita S, Sasaki A, Tanne K, Publico AS, Moss ML. 2001. The nature of human craniofacial growth studied with finite element analytical approach. Clin Orthod Res 4:148-160.

\section{3}

Moss ML. 2003. Discussion of: Effect of unilateral partial facial paralysis on periosteal growth of the musclebone interface of facial muscles and facial bones. Plast Reconstr Surg 111: 1444-1445. 
Sasaki A, Takeshita S, Publico AS, Moss ML, Tanaka E, Ishino Y, Watanabe M, Tanne K. 2004. Finite element growth analysis for the craniofacial skeleton in patients with cleft lip and palate. Med Eng Phys 26:109-118.

2005

Moss ML, Moss-Salentijn L, Hasselgren G, Ling H. 2005. A quantum biological hypothesis of human secondary dentinogenesis. Med Hypotheses 64:479-486.

Thackeray JF, Braga J, Moss ML, Dasgupta G, Treil J, Prat S, Solimene A. 2005. Temporal lines and probabilities of sagittal crest development. Ann Transvaal Museum, Pretoria 42:94-96.

[An electronic version of this bibliography is available on request. Editor]

\section{DAA Subscription}

The secretary-treasurer of the Dental Anthropology Association is Dr. Loren R. Lease of Youngstown State University.

Dr. Loren R. Lease

Department of Sociology and Anthropology

Youngstown State University

One University Plaza

Youngstown, Ohio 44555 USA

Telephone: (330) 941-1686

E-mail: 1rlease@ysu.edu

Dental Anthropology now is published electronically and e-mailed to all members as a PDF. If you also want to receive a hard copy, be sure to make this clear on the membership form at the DAA website or contact Loren.

Speed communication about your membership by contacting Loren directly (other officers may not have current membership lists). 